\title{
Determinants of Wheat Market Outlet Choice of Smallholder Farmers: The Case of Dembecha District, Amhara National Regional State, Ethiopia
}

\author{
Yonnas Addis $^{1 *} \quad$ Bosena tegegn $^{2} \quad$ Mengistu Ketema $^{2}$ \\ 1. Lecturer, Department of Agribusiness and Value Chain Management, Wolkite University, , Wolkite, Ethiopia. \\ P.O. Box 07. Phone no +251929957521 \\ 2.School of Agricultural Economics and Agribusiness, Haramaya University, Ethiopia
}

\begin{abstract}
Wheat is one of the major cereal crops produced in Ethiopia and used as food and source of cash for farm households. This study aimed identifying factors affecting market outlet choice of wheat farmers in Dembecha district of Ethiopia. A total of 130 farm households were used to collect primary data. About 48.5\%, 62.3\%, $71.5 \%$ and $51.2 \%$ of respondents had chosen wholesalers, collectors, cooperatives, and consumers outlets, respectively. The multivariate probit model used revealed the choice of wholesale's outlet positively affected by educational level and quantity supplied; and negatively by family size and cooperative membership. The choice of collectors' outlet is negatively affected by educational level and positively by quantity supplied; while choice of cooperative outlet is positively affected by extension contact and membership in cooperatives. Similarly, the choice of consumer outlet is positively affected by educational level, farming experience and extension service. It is, therefore, important to strengthen extension service, efficiently using resources, promoting cooperatives membership and farmers experience to assist farmers producing more and choose a more rewarding market outlet.
\end{abstract}

Keywords: Market outlet choices, Multivariate probit, Smallholder, Wheat

DOI: $10.7176 / \mathrm{JPID} / 50-02$

Publication date:June $30^{\text {th }} 2019$

\section{Introduction}

Wheat (Triticum aestivum.) is the first important and strategic cereal crop for the majority of world's populations. It plays an important role in the development of the agricultural sector and improvement in the income levels and livelihood situations of the farmers in developing countries. It is the fourth important crop in term of total gross value production and the second importance food next to maize in Ethiopia (FAO, 2015; Endalew et al., 2015).

In Ethiopia, wheat is produced on 1,696,082 hectares with an average national yield of 26.75 quintals per hectares in the main cropping season and shown 1.89 percent increment in total from 2015/16 production season. It is mostly grown in the highland and mid highland areas of the country like South East, Central and North West parts. Among nine regions of the country Oromia, Amhara and Southern Nations, Nationalities, and Peoples Region (SNNPR) produces $59 \%, 27 \%$ and $9 \%$ of the country's total wheat production, respectively (USAID, 2016).

The investment made by smallholder farmers and those made by large-scale domestic agribusiness investors on wheat production has increased all over the country due to the improvement in production and increased consumption (Mary et al., 2012). This may be due to changes in population size, urbanization, increased new wheat processing industry, capacity improvement for the existing industry and demand for dietary composition of wheat product. Due to this reason, wheat marketing is becoming as one of the largest sub-sector in the economy and nearly $20 \%$ of the productions are marketed annually, which makes it second next to teff (CSA, 2017).

Wheat crop has a number of marketing alternatives and it has a bit higher complex channels than any other cereal crops and also the volume of wheat flown in to the market and end receiver within the outlets significantly differs for each outlet (AACCSA, 2017). Understanding of the existing market alternative, market channels and the existing opportunities and challenges on using different market alternatives plays fundamental role for designing appropriate technological, policy, organizational and institutional strategies that helps to ensure smallholders and rural poor benefit from the process of different market alternatives. Therefore, increasing smallholder wheat farmers' market return and participation through providing various market opportunities is important to increase the welfare of smallholders.

Decision on the choice among various market alternatives remains the most fundamental task of wheat producers in Ethiopia. Wheat producers use different market alternatives to supply their produce in order to increase earnings from production and to improve their livelihood situation. Several determinant factors have to be considered by smallholder farmers as a basis for making decision to prefer one market outlet over alternatives. On the basis of various empirical studies infrastructural facilities, household characteristics, the existing market 
alternatives, prices, and transportation cost are important factors that smallholder farmers' take into consideration to choose different market outlets (Shewaye, 2016 and Fikru et al, 2017).

A number of studies have been done that have revealed factors influencing marketing channel choice decisions of cereals. Past empirical studies by Sultan (2016) attempted to identify factors affecting wheat market outlet choices among smallholder wheat producers in Oromia Region of Ethiopia. However, there were no comprehensive earlier studies which investigated the factors affecting wheat producers' market outlet choice decision in Dembecha district of Amhara National Regional State where significant amount of wheat has been produced and marketed. Thus, this research was aimed to identify determinants of wheat market outlet choice decision. Therefore, this study attempts to investigate how the characteristics of wheat producers, their resource endowment, production and marketing characteristics, and institutional service delivery jointly affected wheat market outlet choice decision of wheat producing farmers in Dembecha district of north western Ethiopia.

\section{Literature review}

\subsection{Basic concepts of market and marketing}

Market can describe as a point or a place within which price-making force operates and exchanges of title tend to be accompanied by the actual movement of the goods and services being transacted (Backman and Davidson, 1962). This helps to provide households opportunity to be benefited from trading their produces and it enables them to sell their surpluses and purchase goods and services they need, based on comparative advantage (Boughton et al., 2007).

Marketing is a societal process, by which individuals and groups obtain what they need through creating, offering and freely exchanging products, services and values with others. It also includes all activities of exchange conducted by producers and middlemen in exchange for the purpose of satisfying consumer demand (Kilingo and Kariuki 2001). Marketing also involves the movement of produces from their point of production to the point of consumption (Gindi et al., 2014).

\subsection{Market channels and outlets}

A marketing channel is a business structure of interdependent organizations that reach from the point of product origin to the consumer with the purpose of moving products to their final consumption destination (Kotler and Armstong, 2003). Marketing channels are alternative routes of product flows from producers to consumer and it can be either short or long depending on kind and quality of the product marketed, available marketing services, and prevailing social and physical environment (Islam et al., 2001). Peoples market channel and outlet as substitute to one another. However, market outlets refer alternative routes of product flow that producers used directly to supply there produce rather than considering the possible path of product flow in the commodity chain. A market chain is another important concept in market study and it is used to describe the numerous links that connect all the actors and transactions involved in the movement of agricultural goods from the farm to the consumer (Lunndy et al., 2004). This means, it is the path that agricultural goods and products flow up the chain and money flows down the chain from their source of original production to ultimate destination for final use.

\subsection{Smallholder farmer's choice of marketing outlets}

Smallholder farmers are defined as the basis of land and livestock holdings, cultivate less than two hectares of land and own only few herds of livestock (Salami et al., 2010). Dixon et al., (2003) describe smallholders in areas with high population densities, smallholder farmers usually cultivate less than one hectare of land, which may increase up to ten hectares or more in semi-sparsely populated arid areas, in combination up to ten animals. The majority of farmers in Ethiopia are subsistence smallholders, with little separation between production and consumption decisions (Muller, 2014). Smallholders in Ethiopia are known for their resource constraints such as capital, inputs and technology; their heavy dependence on household labor; their subsistence-orientation; and their exposure to risk such as reduced yields, crop failure and low prices (Mahelet, 2007; Diao et al., 2010).

The availability of alternative marketing outlet is one of the key ingredients to successful marketing of agricultural products and increasing market participation of smallholder farmers. This is so because different outlets are characterized by different benefits (profitability) and costs. For instance, the Ethiopian wheat value chain consists of multiple actors and channels. A range of actors that include smallholder farmers, wholesalers, retailers, part-time farmer-traders, brokers, processors, cooperatives, the government and parastatal organizations, and private consumers take part in the wheat value chain (AACCSA, 2017).

\subsection{Analytical framework}

For the analysis of categorical dependent variables more than two choices econometric models such as multivariate probit, multinomial logit, conditional or mixed or nested logit are useful models used by previous researchers. Multinomial models are appropriate when individuals can choose only one outcome from among the set of mutually exclusive, collectively exhaustive alternatives. But, recent empirical studies of market outlet 
choices assume that farmers consider a set (or bundle) of possible outlets and choose the particular marketing outlet that maximizes expected utility (Takele et al., 2017; Kassa et al. (2017; Mekonin, 2017; Addisu, 2018).

Multivariate probit model simultaneously models the influence of a set of explanatory variables on the choice of market outlets, while allowing for the potential correlations between unobserved disturbances, as well as the relationship between the choices of different market outlets (Belderbos et al., 2004). Multivariate probit model is a preferred model because choosing one outlet can be affected by the relative risk of choosing the other (Greene, 2003).

Smallholder farmers may select the market outlet that shows the most positive utility. Wheat supply chain in Ethiopia consists of seven to ten marketing channels or outlets (Woldehanna et al., 2010). Smallholder farmer's decision to select a given market outlet or not is made by evaluating the return in expected utility, taking into account the related investment and transaction costs (Urquieta, 2009).

\subsection{Review of empirical studies}

There are a number of empirical studies on market outlet choice of agricultural commodities:

Addisu (2018) employed multivariate probit (MVP) model to identify factors affecting market outlet choice of teff producers in Dendi district of Oromia, central Ethiopia. The multivariate probit model results revealed that variables like household size number of equines owned, education level of the household head, size of land under tef production, distance from the nearest market, current market prices of tef, and cooperative membership affected the choice of appropriate market outlets of producers.

Takele et al. (2017) identified on important determinants of market outlet choice of smallholder mango producers in Boloso Bombe Woreda, Wolaita zone, Southern Ethiopia using Multivariate Probit model. The result showed that variables such as family size, distance to the market, quantity of mango produced, the price offered, access to market information and access to non- farm income determined the decision of choice of wholesaler, collector, retailer and consumer market outlets at different significance level.

Shewaye (2016) used multivariate probit (MVP) model to identify factors affecting haricot bean market outlet choices in Misrak Badawacho district, Southern Ethiopia. The result of MVP model revealed that distance to all weather roads and distance to the nearest district market positively affect the probability to choose rural assemblers market outlet whereas number of equine owned and use of credit has a negative effect. Number of equine owned positively affects the probability to choose direct consumers outlet. Number of equine owned, use of credit, membership in cooperative and price information positively affect the probability to choose urban traders outlet, whereas distance to the nearest district market negatively affect the probability to choose the urban traders outlet.

Sultan (2016) identified factors affecting wheat market outlet choice of producers at Sinana district of Bale zone, Ethiopia using multinomial logistic regression model and he indicated that compared to accessing assembler market outlet, wholesalers market outlet are influenced by frequency of extension contact, distance from market place, own price of the commodity and membership to cooperative while that cooperative wheat market outlet influenced by price given to the commodity at different outlets.

Mekonin (2017) used Multivariate Probit model to determine market outlet choice and livelihood outcomes of coffee producing farmers in Lalo Assabi district, Oromiya, Ethiopia and they confirmed that, extension contact, education, market distance, non/off-farm income, and cooperative membership influence outlet choice decisions in all outlet channels selected.

Sunga (2011) identified on the basic factors influencing bean producers "choice of marketing channels in Zambia. His results from Multivariate probit model indicated that the choice of marketing channel is directly influenced by the price of beans, scale of operation (as measured by the quantity of beans harvested, and quantity sold), distance to the market, farming mechanization used and livestock ownership were significant determinants of bean producers' choice in Zambia.

\section{Research methods}

\subsection{Description of the study area}

Particularly the study was undertaken in Dembecha district. The district is one of the 15 districts of the West Gojjam zone in Amhara National Regional State. Dembecha is the name of the district as well as administrative center of the district and it is located at $205 \mathrm{~km}$ away from Bhirdar town, Amhara reginal capital in western direction on the main road from Bahir Dar to Addis Ababa. Dembecha is bordered on the west by Bure, on the northwest by Jabi Tehnan, on the north by Dega Damot, and on the east and south by East Gojjam zone. Towns in Dembecha district include Addis Alem, Dembecha, Zeleka and Yechereka. The district has 29 kebeles of which, 25 are rural while 4 are urban kebeles (DDLR, 2017).

Agricultural production is the main means of livelihoods in the district. The main crops produced in the area include maize, wheat, sorghum, teff and pepper. Livestock husbandry is dominated by cattle, sheep, goats, horse and donkey. The altitude of the district ranges from 1500 to 2999 meter above seas level. The agro ecological 
condition of Dembecha district is suitable for the production of cereals and grain legumes. About $87 \%$ of land area in the district lies in mid-highland (Woinadega) whereas the remaining $12 \%$ is high land (dega) and less than $1 \%$ is lowland (kolla). The district has monomodal rainfall distribution with average annual rainfall reaching 1006mm (DDBoA, 2017).

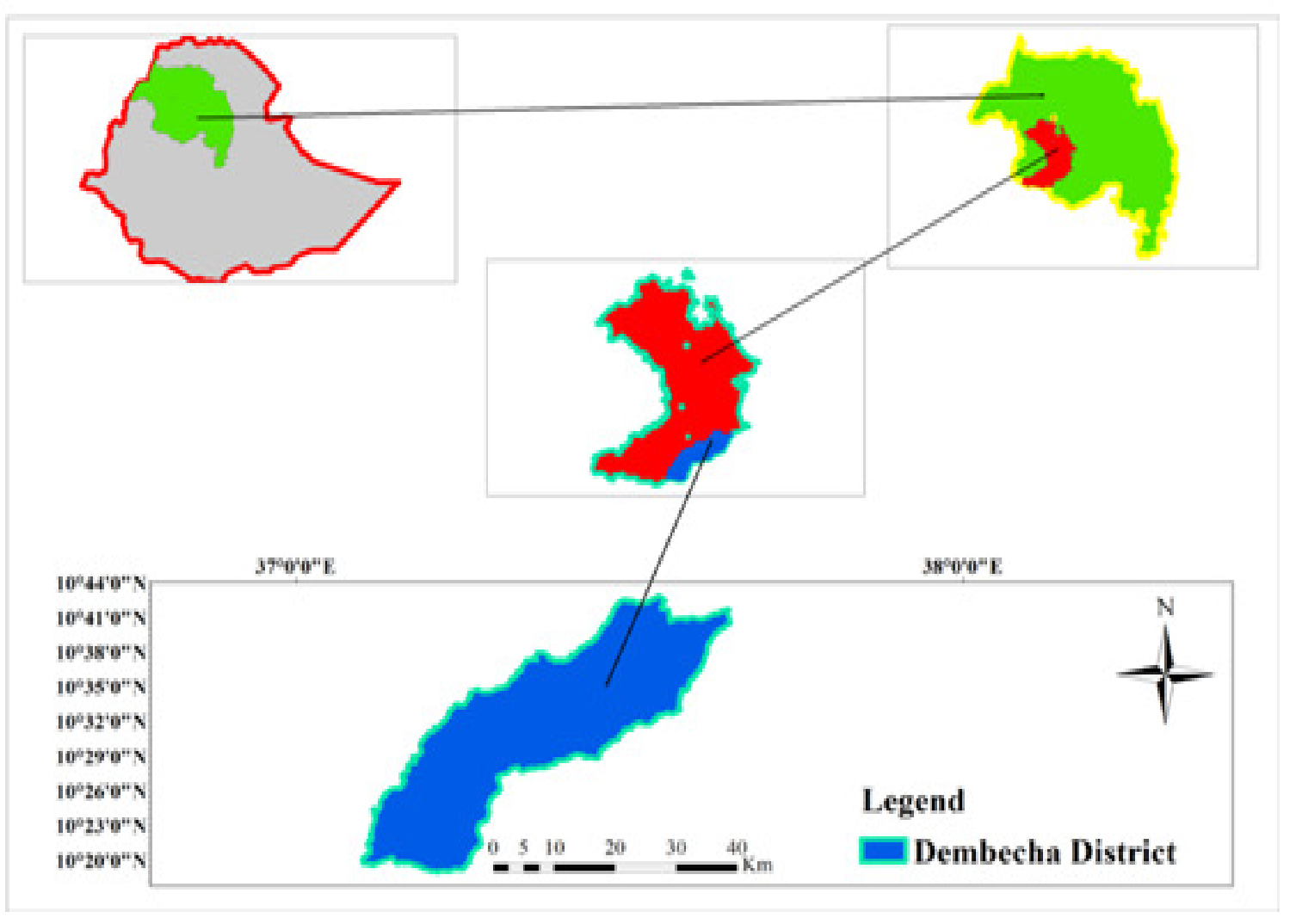

Figure 1: Location of the study area

\subsection{Data source and collection method}

The data for this study was collected from both primary and secondary sources. Primary data about household level demographic, socio-economic characteristics, smallholder resource endowments, infrastructure, market distance, extension services and farm level specific characteristics were collected through pre-tasted semistructured interview schedule. Checklists were to collect data from key informants and focus group discussion participants. Secondary data required for the study were taken from a district's own records, government publications, and journal.

\subsection{Sampling technique and sample size determination}

A stratified three stage sampling technique was employed to select the required samples of households. In the first stage, seventeen wheat producing kebeles were selected from a total of twenty five wheat producing kebeles based on relative production potential. Then, in the second stage, four kebeles namely Zeleka, Egziabiharab, Jajjirab and Wad were selected randomly. Finally, in the third stage wheat producers from the sample kebeles with the intended sample size were selected randomly by using probability proportion to population size sampling technique.

The study used a total sample size $(n=134)$ was drawn from a total of 4527 wheat producing households and it was determined following a simplified formula provided by Yamane (1967). Accordingly, the required sample size at $95 \%$ confidence level with degree of variability of $5 \%$ and level of precision equal to $8.5 \%$ were used to obtain a sample size required to represent the true population.

$$
n=\frac{\mathrm{N}}{1+\mathrm{N}(\mathrm{e})^{2}}
$$

Where: $\mathrm{n}=$ sample size, $\mathrm{N}=$ population size (sampling frame) and $\mathrm{e}=$ level of precision. 


\subsection{Econometric model specification}

In the study area, wheat flows through four market outlets. These are through wholesalers, collectors, cooperatives and consumers. Wheat producers of the district used one or several combinations of four outlets to maximize their benefit. Multivariate probit model takes into account the potential interdependence in market outlet choices and the possible correlation in the choice of alternative outlets. It is also one form of a correlated binary response regression model that simultaneously estimates the influence of independent variables on more than two dependent variables, and allows for the error terms to be freely correlated. The dependent variable is represented by one if the outlet is chosen and zero otherwise.

Considering the possibility of simultaneous choices of outlets and the potential correlations among these market outlet choice decisions multivariate probit model (mvprobit) was appropriate and applied to capture household variation in the choice of market outlets and to estimate several correlated binary outcomes jointly.

The observed outcome of market outlet choice can be modeled by the following random utility formulation. Consider the $\mathrm{i}^{\text {th }}$ farm household $(\mathrm{i}=1,2 \ldots \ldots \mathrm{N})$, facing a decision problem on whether or not to choose available market outlets. Let $U_{o}$ represent the benefits to the farmer who chooses wholesalers and let $U_{k}$ represent the benefit of farmer to who choose the $\mathrm{K}^{\text {th }}$ market outlets: where $\mathrm{K}$ denotes choices of wholesalers $\left(\mathrm{Y}_{l}\right)$, collectors $\left(\mathrm{Y}_{2}\right)$, cooperatives $\left(\mathrm{Y}_{3}\right)$ and consumers $\left(\mathrm{Y}_{4}\right)$. The farmers decide to choose the $\mathrm{K}^{\text {th }}$ market outlet if:

$$
Y_{i k}^{*}=U_{k}^{*}-U_{o}>0 \text {. }
$$

The net benefit ( $Y_{i k}^{*}$ ) that the farmer derives from choosing a market outlet is a latent variable determined by observed explanatory variable $(\mathrm{Xi})$ and the error term $\left(\varepsilon_{\mathrm{i}}\right)$ :

$$
Y_{i k}^{*}=x_{i}^{\prime} \beta_{k}+\varepsilon_{i} \quad\left(k=Y_{1}, Y_{2}, Y_{3}, Y_{4}\right)
$$

Where, in this study, $Y_{1}=$ wholesalers, $Y_{2}=$ collectors, $Y_{\mathrm{a}}=$ cooperatives and $Y_{4}=$ consumers. Using the indicator function, the unobserved preferences in the above equation translates into the observed binary outcome equation for each choice as follows:

$Y_{i k}=\left\{\begin{array}{l}1 \text { if } x_{i}^{\prime} \beta_{k}+\varepsilon_{i}>0 \\ 0 \text { if } x_{i}^{\prime} \beta_{k}+\varepsilon_{i} \leq 0\end{array} \quad\left(K=Y_{1}, Y_{2}, Y_{3} Y_{4}\right)\right.$

Where: $\mathrm{x}^{\prime}$ is a vector of explanatory variables;

$\beta$ denotes the vector of parameters to be estimated; and

$\varepsilon$ are random error terms distributed as multivariate normal distribution with zero mean and unitary variance.

$Y_{i}$ is a set of binary dependent variables such that: $Y_{1}=$ Wholesaler, 1 for the farmer who choose wholesalers, 0 otherwise; $\mathrm{Y}_{2}=$ Collector, 1 for the farmer who choose collectors, 0 otherwise; $\mathrm{Y}_{3}=$, Cooperativ1 for the farmer who choose Cooperative, 0 otherwise and $Y_{4}=$ Consumer, 1 for the farmer who choose consumers, 0 otherwise.

In multivariate probit model, where the choice of several market outlets is possible the error terms jointly follow a multivariate normal distribution $(\mathrm{MVN})$ with zero conditional mean and variance normalized to unity (for identification of the parameters) where $\left(\mu_{y 1}, \mu_{v 2}, \mu_{v 3}, \mu_{y 4}\right) M V N \sim(0, \Omega)$ and the symmetric covariance matrix $\Omega$ is given by:

$$
\Omega=\left[\begin{array}{cccc}
1 & \rho_{y 1 y 2} & \rho_{y 1 y 3} & \rho_{y 1 y 4} \\
\rho_{y 2 y 1} & 1 & \rho_{y 2 y 3} & \rho_{y 2 y 4} \\
\rho_{y 3 y 1} & \rho_{y 3 y 2} & 1 & \rho_{y 3 y 4} \\
\rho_{y 4 y 1} & \rho_{y 4 y 2} & \rho_{y 4 y 3} & 1
\end{array}\right]
$$

From the above equation off-diagonal elements in the covariance matrix represents the unobserved correlation between the stochastic components of the different type of outlets and the above equation generates a 
MVP model that jointly represents decision to choose particular market outlet. This specification with non-zero off-diagonal elements allows for correlation across error terms of several latent equations, which represents unobserved characteristics that affect the choice of alternative market outlets. Following the form used by Cappellari and Jenkins (2003), the log-likelihood function associated with a sample outcome is given by:

$\ln L=\sum_{i=0}^{N} \omega_{i} \ln \Phi\left(\mu_{i}, \Omega\right)$

Where $\omega_{j}$ is an optional weight for observation $i$, and $\Phi$ is the multivariate standard normal distribution with arguments $\mu_{\mathrm{i}}$ and $\Omega$, where $\mu_{\mathrm{i}}$ can be denoted as;

$$
\begin{aligned}
& \mu_{i}=\left(k_{i 1} \beta_{1} x_{i 1} k_{i 2} \beta_{2} x_{i 2,} k_{i 3} \beta_{3} x_{i 3}\right), \text { While } \mathbf{\Omega}_{\mathrm{ik}}=\mathbf{1} \text { for } \mathbf{j}=\mathbf{k} \text { and } \\
& \mathbf{\Omega}_{\mathrm{ik}}=\mathbf{\Omega}_{\mathrm{hj}}=k_{i j} k_{j k} \rho_{j k} \text { for } j \neq k, k=1,2,3 \ldots . \text { With } k_{i k}=2 y_{i k}-1
\end{aligned}
$$

\subsubsection{Hypothesized variables}

The potential variables, which were supposed to influence wheat producers' market outlet, need to be explained. Hence, the explanatory variables expected to have influence are summarized as follows (Table 1):

Table 1: Summary of hypothesized variable for market outlet choice decision

\begin{tabular}{ll}
\hline Variable & \multicolumn{1}{c}{ Type } \\
\hline $\begin{array}{l}\text { Dependant variable } \\
\text { Market outlet choice }\end{array}$ & $\begin{array}{l}\text { 1. Wholesale's outlet, } 2 \text { Collector outlet, 3. Cooperatives outlet, } \\
\text { 4. Consumers outlet }\end{array}$ \\
\hline Independent variable & Dummy 1 if male, 0 otherwise \\
\hline Sex of a household head & Continuous (in years of schooling) \\
Educational level of a household head & Discrete (in number) \\
Family size & Continuous (in Quintal) \\
Quantity sold & Continuous (in years) \\
Wheat farming experience & Continuous (number of contact per year)) \\
Frequency of extension contact & Continuous (in km) \\
Distant to nearest market & Continuous (in TLU) \\
Livestock holding & Dummy 1 if yes, 0 otherwise \\
Non/off farm income & Dummy 1 if yes, 0 otherwise \\
Transport ownership & Dummy 1 if yes, 0 otherwise \\
Cooperative membership &
\end{tabular}

Source: reviewed literature

\section{Result and Discussion}

\subsection{Characteristics of the sampled respondents}

From a total of 134 sample household heads interviewed, $89.23 \%$ were male-headed households while $10.77 \%$ were female-headed households. Regarding household size, the mean household size of sample households was 4.52. Concerning their educational level, the mean year of schooling of respondents was 2.74 . The mean wheat production experience of respondents was 19.22 years with maximum of 43 and the minimum experience of 6 years.

Moreover, the mean livestock holding of the sampled households in terms of tropical livestock unit (TLU) was 4.50 , the maximum and minimum being 8.55 and 2.15 TLU, respectively. The average size of land allocated for wheat by farm households during the surveyed year was 0.89 ha with minimum and maximum of 0.125 ha and 2 ha, respectively. The average quantity of wheat produced by sample households in the study area is 22.92 quintals and averagely 16.86 quintal was marketed in 2016/17 production years. Regarding number of extension contact, sample households had contacted development agents about 5.09 times in a year with maximum and minimum contacts of 12 and 0 , respectively (Table, 2 ). 
Table 2: Socioeconomic characteristics of sample respondents

\begin{tabular}{lcccc}
\hline Continuous Variables & Mean & Std. Dev. & Min & Max \\
\hline Educational level (Years of schooling) & 2.75 & 2.87 & 0 & 10 \\
Land allocated to wheat (Hectare) & 0.89 & 0.40 & 0.125 & 2 \\
Quantity produced (Quintal) & 22.92 & 9.60 & 4 & 48 \\
Quantity sold (Quintal) & 16.86 & 7.45 & 5 & 40 \\
Wheat farming experience (Years) & 19.22 & 8.30 & 6 & 43 \\
Family size (Number) & 4.52 & 1.77 & 2 & 8 \\
Distance from nearest market (Km) & 4.45 & 3.24 & 0.5 & 12 \\
Extension contact (Number) & 5.09 & 3.96 & 0 & 12 \\
Tropical livestock unit (TLU) & 4.50 & 1.56 & 2.15 & 8.55 \\
Dummy variables & Proportion & & & \\
Sex of household heads (male) & 0.89 & & & \\
Non/off farm income (yes) & 0.40 & & & \\
Transport ownership (yes) & 0.50 & & & \\
Cooperative membership (yes) & 0.68 & & & \\
\hline So & & &
\end{tabular}

Source: own survey 2017

\subsection{Marketing Channels of Wheat}

Market channel analysis is important to provide a systematic knowledge of the flow of products from producers to consumers (Mendoza, 1995). Therefore, wheat market channel for this study were designed based on the direction and volume of flow of product (wheat) passing through different routes during the 2016/17 production year.

The following figure depicted the most important channels and volume of product flow:

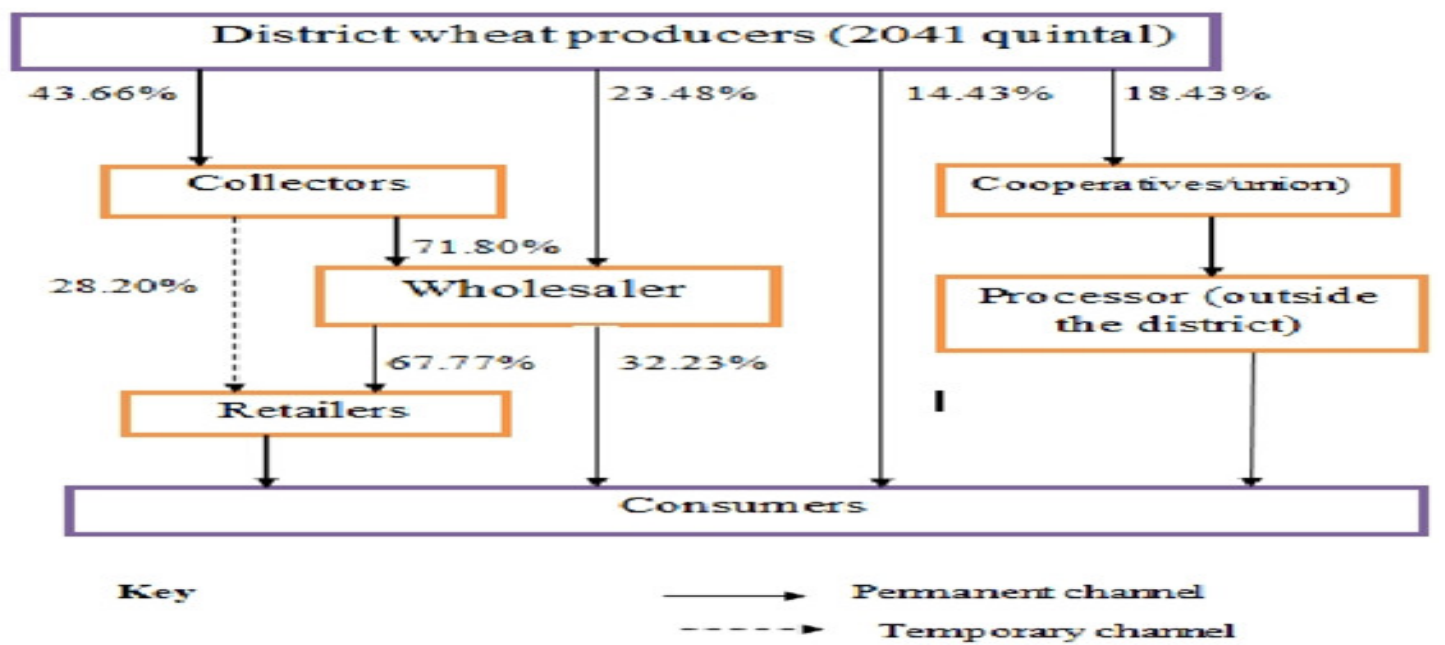

Figure 2: Market channel of wheat in Dembecha district of West Gojjam zone

As depicted in figure below, seven wheat-marketing channels were identified that passed the product from producer to consumers. The major actors in the channel were producers, cooperatives, collectors, wholesalers, retailers and consumers. According to survey result, a total of 3516 quintals of wheat was produced by the sample wheat producers' households in the year 2016/17. Of this, the amount that was transacted during the year was found to be 2041 quintals. From the marketed surplus, 433.71 quintals (21.25\%) passed through channel IV followed by channel VII which shares about 376.15 quintals $(18.43 \%)$ quintals which were found to be uppermost in terms of wheat volume of marketed. On the other hand, the least volume of wheat passed through channel V, which accounts 154.50 quintal (7.57\%) from the total volume marketed by sample households.

\subsection{Wheat marketing outlets}

The sample wheat producer households used different market outlets to supply wheat to market. The study showed four wheat market outlets which are wholesales, collectors, cooperatives and consumers. These outlets are mostly chosen in combination with one another. 
Table 3: Description of wheat market outlets

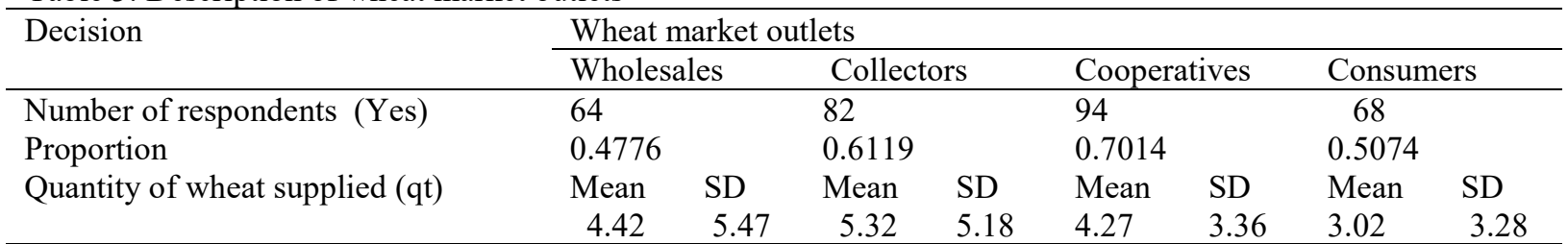

As indicated in Table 3, about $47.76 \%, 61.19 \%, 70.14 \%$, and $50.74 \%$ of sample households sold their wheat produce via wholesaler, collector, cooperatives, and consumers' market outlets, respectively. Cooperative market outlet was the first important channel chosen by most producers $(70.14 \%)$ with average amount of wheat supplied to market of 4.27 quintal. This may be due to the fact that cooperatives are the most important input providers in the study area and wheat producers should supply wheat produce to cooperatives to get inputs and other benefits from cooperatives easily. However, cooperatives market outlet received relatively lowest quantity of wheat marketed. Collector's market outlet was also the first in terms of quantity of wheat supplied to market with mean value of 5.32 quintals and $61.19 \%$ of sample wheat producers supplied to collectors.

\subsection{Determinants of wheat producers market outlet choices}

The estimate of the multivariate probit model fits the data reasonably well. The statistical significance of the model is examined by using a likelihood ratio test of the null hypothesis that all slope estimates are zero. The Chi square statistic with 44 degree of freedom is 84.71 indicating rejection of the null hypothesis at $1 \%$ significant level. This means the explanatory power of the factors included in the model is excellent. The results of likelihood ratio test in the model (LR $\left.\chi^{2}(6)=30.19, \chi^{2}>\mathrm{p}=0.0000\right)$ is statistically significant at $1 \%$ level indicating that the independence of the disturbance terms (independence of four market outlets choice) is rejected. The correlation coefficients are statistically different from zero in 3 of the 6 cases, confirming the appropriateness of the multivariate probit specification and choice of market outlets are not mutually independent.

The result of multivariate probit model showed that the likelihood of households to choose wholesale, collector, cooperative and consumer outlet were $48.7 \%, 62.97 \%, 71.61 \%$ and $50.71 \%$, respectively. This implies that the likelihood of wheat producers to choose cooperative outlet is relatively high $(71.61 \%)$ as compared to that of choosing collectors outlet $(62.97 \%)$ and consumer's outlet $(50.71 \%)$.

The model result also revealed that the joint probabilities of success or failure of choosing the four market outlets suggested that households are more likely to fail to jointly choose the four outlets. The likelihood of households to jointly choose the four outlets is only $8.62 \%$ compared to their failure to jointly choose all four outlets which was about 10.6 (Table 4).

Eleven explanatory variables were hypothesized to affect the choice of wheat market outlet alternatives, six variables significantly determined market outlet choice decision. Among these variables, four variables determined more than one market outlet while two variables determined only one market outlet choice.

Educational level of a household heads significantly and positively affected the likelihood of choosing wholesalers' and consumers' market outlet choices at 5\% and $1 \%$ level of significance, respectively, and negatively affected collectors' market outlet at 5\% level of significance. This is because spending more years in formal education makes producers better to recognize profits/benefits from selling through different market outlets and become wise in the choice of best outlets. Hence, educational level of households is considered as an important factor to participate actively in different outlets. Study by Mengistu et al. (2016) showed the positive and significant relationship between formal year of schooling and wholesalers and retailers outlet. Study by Taye et al. (2018) also showed negative and significant relationship of collectors' outlet and formal years of schooling in onion market outlet choice decisions. The above listed findings are in line with these findings.

Family size of households determined choice of wholesalers' market outlet negatively and significantly at 5 percent level of significance. Households with larger family size are less likely to choose wholesalers market outlet; rather they prefer to supply to either collectors and or cooperatives outlets where they can find at relatively near distance or to consumers outlet to which most producers sell when small volume is available for sale. The result is in line with study of Takele et al. (2017) who showed family size decrease the amount of mango available for sale and negatively related with wholesale's market outlet.

Quantity of wheat sold is also another significant variable affecting the likelihood of choosing wholesale's and collector's market outlet positively at 1 percent significance level. This is due to the fact that when large volume of wheat is available for sale, producers have a propensity to find a potential buyers that can absorb such large volume and thereby wholesalers and collectors are expected to satisfy such need with better financial strength and purchasing power than consumers. This reduces the probability of supplying to a consumer outlet which requires a number of market days with relatively smaller volume of supply in particular market day. 
Table 4: Determinants of wheat producers' market outlet choice multivariate probit result

\begin{tabular}{|c|c|c|c|c|}
\hline \multirow[t]{2}{*}{ Explanatory variables } & $\begin{array}{l}\text { wholesale's } \\
\text { outlet }\end{array}$ & $\begin{array}{c}\text { Collectors' } \\
\text { outlet }\end{array}$ & $\begin{array}{c}\text { Cooperatives } \\
\text { outlet's }\end{array}$ & $\begin{array}{c}\text { Consumer } \\
\text { outlet's }\end{array}$ \\
\hline & Coef (Std. error) & Coef (Std. error) & Coef (Std. error) & Coef (Std. error) \\
\hline Sex of a household head & $2.35(1.526)$ & $-0.07(0.386)$ & $-0.12(0.4333)$ & $0.1(0.435)$ \\
\hline $\begin{array}{l}\text { Educational level of a } \\
\text { household head }\end{array}$ & $0.16(0.065)^{* *}$ & $-0.07(0.386)^{* *}$ & $-0.12(0.4333)$ & $0.12(0.0438)^{* * *}$ \\
\hline Family size & $-0.24(0.114)^{* *}$ & $0.0003(0.076)$ & $0.07(0.083)$ & $-0.1(0.0768)$ \\
\hline Quantity of wheat sold & $0.17(0.0377)^{* * *}$ & $0.08(0.026)^{* * *}$ & $0.01(0.0216)$ & $-0.02(0.0208)$ \\
\hline Wheat farming experience & $0.03(0.022)$ & $-0.016(0.0164)$ & $-0.014(0.017)$ & $0.03(0.016)^{*}$ \\
\hline Extension contact & $0.02(0.048)$ & $-0.014(0.040)$ & $0.06(0.0376)^{*}$ & $0.09(0.0375)^{* *}$ \\
\hline $\begin{array}{l}\text { Distance to the nearest } \\
\text { market }\end{array}$ & $-0.08(0.058)$ & $0.04(0.0436)$ & $-0.03(0.045)$ & $-0.02(0.0424)$ \\
\hline Livestock holding & $0.13(0.110)$ & $-0.05(0.0792)$ & $-0.08(0.0829)$ & $0.003(0.0806)$ \\
\hline Off/non-farm income & $0.12(0.303)$ & $0.366(0.2496)$ & $-0.35(0.254)$ & $0.25(0.250)$ \\
\hline Transport ownership & $0.37(0.302)$ & $-0.26(0.2578)$ & $0.24(0.266)$ & $-0.07(0.250)$ \\
\hline Cooperative ownership & $-0.92(0.341)^{* * *}$ & $-0.19(0.261)$ & $0.82(0.258)^{* * *}$ & $0.20(0.253)$ \\
\hline Constant & $-5.07(1.922) * * *$ & $-001(0.691)$ & $0.21(0.748)$ & $-0.66(0.729)$ \\
\hline Rho2 & $-0.38 * *$ & & & \\
\hline Rho3 & $-0.57 * * *$ & -0.08 & & \\
\hline Rho4 & 0.08 & $-0.37 * * *$ & -0.19 & \\
\hline Predicted probability & 0.487 & 0.6297 & 0.7161 & 0.5071 \\
\hline $\begin{array}{l}\text { Joint probability(success) } \\
\text { Joint probability(failure) }\end{array}$ & & & & $\begin{array}{l}0.0862 \\
0.0106\end{array}$ \\
\hline Number of observations & & & & 130 \\
\hline Log likelihood & & & & -252.02 \\
\hline Wald $\chi 2(44)$ & & & & 84.71 \\
\hline Prob $>\chi^{2}$ & & & & 0.0002 \\
\hline Likelihood ratio test of Rhoij & & & & 30.19 \\
\hline $\begin{array}{l}=0 \\
P>\chi 2(6)\end{array}$ & & & & 0.0000 \\
\hline
\end{tabular}

Wheat farming experience affected choice of consumers' outlet positively and it is significant at 10 percent level. Farmers who stayed in wheat farming business may have more market information and knowledge. Past experience provides farm households knowledge to understand best market outlet which is consumers market outlet where they can get 100 percent marketing margin.

Frequency of extension contact on either production or market related issues affected the choice of cooperatives' and consumers' outlet positively at 10 and 5 percent significance levels, respectively. The positive sign shows that farmers who obtained more number of extension contacts with development agents are more likely to sell wheat to cooperatives and consumers market outlets in order to capture profit taken by other traders. Extension service helps farmers in improving and using new production technology as well as in getting awareness about markets (absolute advantage from using better market outlets). This study is in line with Kassa et al. (2017) who found positive relationship between extension contact and cooperatives, retailers and consumers outlets.

Similarly, membership to cooperatives has significant influence on market outlet choices. Household membership in cooperative provides better access to information, agricultural inputs and other benefits. Participation in cooperative market also contributes towards reducing transaction costs. Households who are members of cooperatives showed interests to sale wheat to outlets at relatively near distance. The result revealed that being a member in cooperatives increases the likelihood of choosing cooperatives' outlet and reduces the likelihood of choosing wholesalers' outlet. This result is against a study by Sultan (2016) who found negative relationship between memberships to cooperatives and selling to cooperatives' outlet.

\subsection{Conclusions and implications}

In this study, factors affecting wheat market outlets choice were analyzed using multivariate probit model. The result indicated that the outlet choice of wholesalers was significantly and positively influenced by educational level of household heads and volume of wheat supply; and negatively by family size and cooperative 
membership. Collectors' market outlet choice was affected significantly and negatively by education level of households and quantity supplied at 5 and 1 percent significance levels, respectively. Cooperatives' market outlet is another producers' route in which extension contact and cooperative membership were significant variables affecting it. Whereas consumers' outlet was positively and significantly affected by educational level of household head, wheat farming experience, and frequency of extension contact at 1,10 and 5 percent significance levels, respectively.

Based on the findings of this study, some relevant implications is drawn to assist in designing appropriate intervention mechanisms that help to improve wheat producers' benefit from alternative market outlets in the study area. Extension education needs to be strengthened. It is also necessary to increase quantity supplied to market by increasing production through efficient use of resources, strengthening extension service, promoting farmers experience through training and model farmers filed visit, organizing non-cooperative member producers into cooperatives to build up capacities and for better bargaining ability.

\section{References}

AACCSA [Addis Ababa Chamber of Commerce and Sectoral Association] (2017), Value Chain Study on Wheat Industry in Ethiopia: By Afro Universal Consult \& General Trading P.L.C. Addis Ababa, Ethiopia.

Addisu, G. (2018), Determinants of commercialization and market outlet choices of tef: the case of smallholder farmers in Dendi district of Oromia, central Ethiopia. Master Thesis. Haramaya University, Ethiopia

Backman, T.N. and Davidson, W.R. (1962), Marketing principle. The Ronal Presses Co., New York. pp. 3-24.

Belderbos, R., Carree, M., Diederen, B., Lokshin, B. and Veugelers, R. (2004), Heterogeneity in R\&D cooperation strategies. International Journal of Industrial Organization, 22(2004): 1237-1263.

Boughton, D., Mather, D., Barret, C.B., Benfica, R., Abdula, D., Tschirley, D. and Cunguara, B. (2007), Market participation by rural households in a low-income country: An asset-based approach applied to Mozambique. Faith and Economics, 50 (2007): 64-101.

Cappellari, L., Jenkins, S.P. (2003), Multivariate probit regression using simulated maximum likelihood. The Stata Journal 3(3): 278-294.

CSA [Central Statistical Agency] (2017), Area and Production of Major Crops (Private Peasant holdings, meher seasons). Addis Ababa Ethiopia, The FDRE statistical bulletin Volume I: 01-532.

DDBoA [Dembecha District Agricultural office] (2017), Estimated land allocated to various Agricultural crops, unpublished source, Dembecha, Ethiopia.

DDLR [Dembecha District Livelihood Report] (2017), Dembecha Woreda Livelihood Profile Manual Document. Unpublished source, Dembecha.

Diao, X., Alemayehu Seyoum, Yu, B. and Pratt, A.N. (2010), Economic Importance of Agriculture for Sustainable Development and Poverty reduction: the case study of Ethiopia. OECD project report on Global report on Agriculture, 29-30 November 2010. Policies for Agricultural Development, Poverty Reduction and Food Security. Paris, France.

Dixon, J., Taniguchi, K. and Wattenbach, H. (2003), Approaches to assessing the impact of globalization on African smallholders: Household and village economy modeling. Proceedings of a Working Session on Globalization and the African Smallholder Study, 10-13 November 2003.

Endalew, B., Muche, M., Tadesse S. (2015), 'Assessment of food security situation in Ethiopia': A Review. Asian J Agric Res 9(2): 55-68.

FAO [Food and Agriculture Organization] (2015), the state of food insecurity in the world.

Fikru, T., Efa, G., Hailu, M. (2017), Analysis of Sesame Marketing Chain in Case of Gimbi Districts, Ethiopia. Journal of Education and Practice (8): 86-102.

Greene, W. (2003), Econometric Analysis, $5^{\text {th }}$ Edition. Prentice-Hall, Upper Saddle River, New Jersey, 07458. New York University.

Islam, M., H. Miah, and Haque M. (2001), Marketing system of marine fish in Bangladesh. Bangladish Journal of Agricultural Economic, 24(2): 127-142.

Kassa, T., Jema, H., Bosena, T. (2017), Determinants of honey producer market outlet choice in Chena District, southern Ethiopia: journal of Agricultural and Food Economics. https://doi.org/10.1186/s40100-0170090-0

Kilingo, J.K. and Kariuki J.G. (2001), Marketing of Smallholder Produce.

Kotler, P. and Armstrong, G. (2003), Principle of Marketing, $10^{\text {th }}$ Edition. Hall of India Pvt. Ltd, New Delhi. pp. 5-12.

Lunndy, M., M.V. Gottret, W. Cifuentes, C. F. Ostertag, R. Best, D. Peters and S. Ferris. (2004), Increasing the Competitiveness of Market Chains for Small-holder Producers. Manual 3: Territorial Approach to Rural Grow-enterprise Development. International Centre for Tropical Agriculture. Colombia. 117p.

Mahelet, G. (2007), Factors affecting commercialization of smallholder farmers in Ethiopia: the case of North Omo Zone, SNNP region. Paper Presented at the $5^{\text {th }}$ International Conference on the Ethiopian Economy, 
7-10 June 2007. Addis Ababa, Ethiopia..

Mary, K.G., Anderson, C.L., Kathryn, B., Chew, A. (2012), Wheat value chain in Ethiopia. Evan school policy analysis and research.

Mendoza, G. (1995), a primer on marketing channels and margins. In: Scott, Prices, products and people: Analyzing agricultural markets in developing countries. Lynne Reinner Publishers, Boulder, London, UK: pp.257-276.

Mengistu, K., Mohammed, A., Eyassu, S., Tarekegn, G., Estifanos, H., Yonas, H. (2016), The Dairy Value Chain and Factors Affecting Choice of Milk Channels in Harar and Dire Dawa Areas, Eastern Ethiopia.

Mekonin, A (2017), Determinants of market outlet choice and livelihood outcomes of coffee producing farmers in Lalo Assabi Woreda, Oromiya, Ethiopia. Journal of Economics and Development, Vol.19, pp. 48-67.

Salami, A., Kamara, A.B. and Brixiova, Z. (2010), Smallholder Agriculture in East Africa: Trends, Constraints and Opportunities. Working Papers Series No.105. Africa Development Bank, Tunis, Tunisia.

Shewaye, A. (2016), 'Determinants of Haricot Bean Market Participation in Misrak Badawacho District, Hadiya zone, Southern Nations Nationalities and Peoples Regional State, Ethiopia'. Ethiopian Journal of Agricultural Sciences) (26): 69-81.

Sultan, O. (2016), 'Value chain analysis of wheat for Sinana district, Bale zone, Oromia National Regional State, Ethiopia'. MSc thesis. Haramaya University, Haramaya, Ethiopia.

Sunga, C. (2011), Factors influencing bean producers' choice of marketing channels in Zambia. University of Zambia, Zambia.

Takele, H., Endrias, G., Amsalu, M. (2017), Determinants of Market Outlet Choice of the Smallholder Mango Producers: The Case of Boloso Bombe District, Wolaita Zone, Southern Ethiopia.

Taye, M., Degye, G., Assefa, T. (2018), Determinants of outlet choices by smallholder onion farmers in Fogera district Amhara Region, Northwestern Ethiopia. Journal of Horticulture and Forestry (10): 27-35.

Urquieta, A. (2009), Effects of access to information on farmer's market channel choice: The case of potato in Tiraque Sub-Watershed (Cochabamba - Bolivia). MSc Thesis, Virginia Polytechnic Institute and State University. Blacksburg, Virginia.

USAID [United States Agency for International Development] (2016), the competiveness and trade expansion program: Staple Foods Value Chain Analysis. Country Report Ethiopia.

Woldehanna, T., Bayrau, A., Getnet, K., and Woldegiorigis, T. (2010), A Study on the formulation of policy options and strategies to enhance the participation of producers, traders and processors in the grain market of the Ethiopia commodity exchange. Report Submitted to Ethiopia Commodity Exchange Authority. Ethiopian Development Research Institute (EDRI). Addis Ababa, Ethiopia.

Yamane, T. (1967). Statistics: An Introductory Analysis, $2^{\text {nd }}$ Edition. Harper \& Row, Publisher, New York. pp. 919. 